\title{
EFEKTIVITAS MENDENGARKAN BACAAN AL-QURAN TERHADAP PENURUNAN TINGKAT DEPRESI PADA LANSIA
}

\author{
Listiani Amanah $^{1}$, Santi Esterlita Purnamasari \\ ${ }^{12}$ Universitas Mercu Buana Yogyakarta \\ ${ }^{2}$ santigautama@gmail.com
}

\begin{abstract}
Abstrak
Depresi pada lansia adalah suatu gangguan mental yang dijumpai pada lansia akibat proses penuaan. Depresi yang dialami para lansia menyebabkan gangguan kemampuan lansia untuk beraktivitas sehari-hari. Salah satu cara yang digunakan untuk mengatasi hal tersebut adalah dengan mendengarkan bacaan Al-Quran. Penelitian ini bertujuan untuk mengetahui efektivitas mendengarkan bacaan Alquran terhadap penurunan tingkat depresi pada lansia. Lansia yang mendengarkan bacaan Al-Quran akan mengalami penurunan tingkat depresi sedangkan lansia yang tidak mendengarkan bacaan Al-Quran tidak mengalami penurunan tingkat depresi. Subjek dalam penelitian ini adalah 26 lansia yang tinggal di Panti Sosial Tresna Wredha Unit Budhi Luhur. Desain eksperimen penelitian ini adalah pretest-posttest group design. Pengambilan data menggunakan Beck Depression Inventory (BDI). Analisis data menggunakan teknik non paramaterik yaitu uji wilcoxon dan mannwhitney $U$ test. Hasil analis data terlihat nilai $\mathrm{z}$ sebesar 3,189 dengan probabilitas $=0,001(\mathrm{p}<0,05)$ pada kelompok eksperimen, menunjukkan bahwa ada perbedaan skor depresi sebelum dan sesudah mendengarkan bacaan Al-Quran. Hasil pada kelompok kontrol menunjukkan tidak ada perbedaan skor sebelum dan sesudah dengan nilai $\mathrm{z}$ sebesar 1,633 dan probabilitas $=0,102$ ( $\mathrm{p}>0,05)$. Sedangkan hasil uji posttest kelompok eksperimen dan kelompok kontrol menunjukkan nilai probabilitas sebesar $0,000(\mathrm{p}<0,05)$ yang berarti ada perbedaan skor depresi antara kelompok eksperimen dan kelompok kontrol setelah diberi perlakuan. Hasil tersebut menunjukkan bahwa mendengarkan bacaan Al-Quran efektif untuk menurunkan tingkat depresi pada lansia.
\end{abstract}

Kata Kunci : depresi pada lansia, mendengarkan bacaan Al-Quran

\section{THE EFFECTIVENESS OF LISTENING TO RECITATION OF THE KORAN TO DECREASE THE DEPRESSION LEVEL IN ELDERLY}

\author{
Listiani Amanah ${ }^{1}$, Santi Esterlita Purnamasari ${ }^{2}$ \\ ${ }^{12}$ Universitas Mercu Buana Yogyakarta \\ ${ }^{2}$ santigautama@gmail.com
}

\begin{abstract}
Depression in the elderly is a mental disorder found in the elderly due to the aging process. It causes impaired ability of the elderly to do daily activities. One method used to overcome this problem is to listen to the recitation of the Koran. This study aims to find out the effectiveness of listening to Koran recitation to reduce the level of depression in the elderly. Elderly people who listen to the recitation of the Koran will experience a decrease in the level of depression while the elderly who do not listen to the recitation of the Koran do not experience the same thing. The subjects in this study were 26 elderly people who lived on the Tresna Wredha Social Care Unit. The experimental design of this study was a pretest-posttest group design. The data collection used the Beck Depression Inventory (BDI). The data analysis used non-parametric techniques namely Wilcoxon test and Mann-Whitney $U$ test. The results of the data analyst show that the $z$ value is 3.189 with probability = 0.001 ( $p<0.05)$ in the experimental group, indicating that there are differences in depression scores before and after listening to Koran recitation. The results in the control group show no difference in scores before and after with $z$ values of 1.633 and probability $=0.102(p>0.05)$. While the posttest results of the experimental group and the control group show a probability value of $0,000(p<0.05)$ which meant there are differences in depression scores between the experimental group and the control group after being treated. These results indicate that listening to Koran recitation is effective in reducing depression in the elderly.
\end{abstract}


Keywords: depression in the elderly, listening to Koran recitation.

\section{PENDAHULUAN}

Menurut Undang-Undang No. 13 tahun 1998 tentang Kesejahteraan Lanjut Usia yang dimaksud dengan lanjut usia (lansia) adalah seseorang yang berusia 60 tahun ke atas (Buletin Jendela Data dan Informasi Kesehatan, 2013). Di Indonesia jumlah penduduk lansia terus menerus meningkat. Pada tahun 1970 jumlah penduduk yang mencapai umur 60 tahun ke atas berjumlah sekitar 5,31 juta orang atau $4,48 \%$ dari total penduduk Indonesia. Pada tahun 1990 jumlah tersebut meningkat hampir dua kali lipat yaitu menjadi 9,9 juta jiwa. Pada tahun 2020 jumlah lansia diperkirakan meningkat sekitar tiga kali lipat dari jumlah lansia pada tahun 1990 (Maulana, 2011).

Pertambahan populasi ini diikuti juga oleh semakin kompleksnya permasalahan yang dihadapi para lansia (Sumirta, 2011). Kondisi lansia mengalami berbagai penurunan atau kemunduran baik fungsi biologis maupun psikis. Penurunan fungsi biologis dan psikis ini mempengaruhi mobilitas dan juga kontak sosial. Hal tersebut dapat memicu terjadinya gangguan mental. Depresi merupakan salah satu gangguan mental yang banyak dijumpai pada lansia akibat proses penuaan (Irawan, 2013). Hal yang sama juga dijelaskan oleh Probosuseno (2012), salah satu problem yang paling banyak dijumpai pada lansia adalah isolation yang mencakup masalah depresi.

Direktur Bina Kesehatan Jiwa Kemenkes,

Eka Viora (dalam Sindonews, 2013) mengungkapkan dari 24 juta lansia yang ada saat ini diperkirakan $5 \%$ mengalami gangguan depresi. Diperjelas dari sebuah penelitian yang dicatat oleh Susan Lehmann, Direktur Getriatic Psychiatry di Rumah Sakit John Hopkins (Republika, 2012) menyatakan bahwa depresi berat terjadi pada sekitar $2 \%$ orang dengan usia 65 tahun, dengan serangan depresi ringan sekitar seperempat dari para lansia tersebut. Jumlah penderita depresi lebih tinggi terjadi di panti jompo. Nevid, Rathus dan Greene (2005), juga menyatakan bahwa tingkat depresi lebih tinggi dialami oleh lansia penghuni rumah perawatan atau panti jompo.

Depresi merupakan gangguan psikologis yang paling umum terjadi pada tahun-tahun terakhir kehidupan individu. Depresi merupakan kondisi yang mudah membuat lansia putus asa, kenyataan yang menyedihkan karena kehidupan kelihatan suram dan diliputi banyak tantangan (Maulana, 2011). Diperjelas oleh Irawan (2013) yang mengungkapkan bahwa permasalahan depresi yang dialami para lansia menyebabkan gangguan kemampuan lansia untuk beraktivitas sehari-hari.

Hal tersebut tentunya bertolak belakang dari harapan yang tertuang dalam UU nomor 35 tahun 2009 pasal 138 ayat 1, mengenai jaminan para lansia agar tetap hidup sehat dan produktif secara sosial maupun ekonomis sesuai dengan martabat kemanusian. Para lansia seharusnya mendapatkan jaminan menjalani hidup yang tenang, damai, serta menikmati masa pensiun bersama anak dan cucu, karena masa lansia merupakan tahap akhir dari siklus kehidupan 
manusia (Syamsuddin, 2006).

Depresi menurut World Health Organization (dalam Irawan, 2013) merupakan suatu gangguan mental umum yang ditandai dengan mood tertekan, kehilangan kesenangan atau minat, perasaan bersalah atau harga diri rendah, gangguan makan atau tidur, kurang energi, dan konsentrasi yang rendah. Menurut Beck (1985), depresi pada lanjut usia dapat diamati dari gejala-gejala yang dimanifestasikan secara emosional, kognitif, motivasional, fisik dan vegetatif.

Depresi pada lansia sering berhubungan dengan penyesuaian yang terlambat terhadap kehilangan dalam hidup dan berbagai stresor serta penyakit-penyakit fisik. Lebih lanjut, Soejono, Probosuseno dan Sari (dalam Tamaroh dan Puspitorini, 2008), mengungkapkan ada banyak faktor yang menyebabkan seseorang memiliki depresi sehingga disebut multifaktorial, yaitu gabungan dari beberapa faktor biologis, genetika, psikososial, serta lingkungan. Wilkinson (1992) juga menyatakan bahwa banyak faktor yang menyebabkan munculnya depresi seperti: faktor genetik, faktor behavioral, faktor kognitif, jenis tubuh, perubahan suasana hati, stres, faktor kerentanan, dampak psikis dari penyakit fisik, dan mekanisme psikologis.

Beberapa faktor yang diungkapkan sebelumnya menjadi stresor depresi pada lansia. Salah satu faktor yang dominan adalah faktor kognitif. Hal tersebut sesuai dengan pernyataan Alexopoulos (dalam Irawan, 2013) bahwa gangguan kognitif (penyimpangan kognitif) menjadi salah satu penyebab depresi yang dialami lansia. Penyimpangan kognitif para lansia digambarkan dalam perasaan berdosa, hilangnya harapan, perasaan tidak puas bahkan kehilangan konsentrasi (Suardiman, 2011).

Hubungan mengenai faktor kognitif yang menyebabkan depresi juga dijelaskan oleh Cole dkk, Stader \& Hokanson (dalam Nevid, Greene, \& Ratus, 2005) yang menyatakan bahwa pikiran-pikiran yang negatif dan terdistorsi memiliki hubungan kausal dengan depresi. Cara berpikir individu yang disfungsional dapat muncul sebagai respon terhadap peristiwa hidup yang mengecewakan, kemudian menghasilkan mood yang murung (Nevid, Greene, \& Ratus, 2005). Hal tersebut sesuai dengan penjelasan Kwon \& Oei (dalam Nevid, Greene, \& Ratus, 2005) yang menjelaskan bahwa pikiran-pikiran individu dapat mempengaruhi mood individu dan mood individu dapat mempengaruhi pikiran individu tersebut.

Didasarkan pada asumsi bahwa gangguan depresi disebabkan oleh adanya penyimpangan pemrosesan informasi maka diperlukan teknik intervensi yang tepat untuk mengatasi hal tersebut. Beberapa intervensi psikologis telah terbukti efektif untuk menangani depresi, antara lain melalui terapi kognitif (Floyd, dkk dalam Trimulyaningsih \& Subandi, 2010). Bahkan Trimulyaningsih \& Subandi (2010) juga mengembangkan terapi kognitif yang dipadukan dengan perilakuan religius dan relaksasi.

Pada terapi kognitif terdapat nilai-nilai yang menekankan pada individualistik, materialistik, serta mengesampingkan nilai-nilai spriritualistik (Hodge dalam Trimulyaningsih \& Subandi, 2010). Hal ini tentunya bertentangan dengan nilai yang dianut para lansia sebagai bagian dari masyarakat Indonesia, yang 
umumnya memeluk agama tertentu. Padahal penggunaan teknik yang sesuai dengan nilai yang dimiliki individu akan memberikan hasil yang lebih baik (Hodge dalam Trimulyaningsih \& Subandi, 2010). Untuk itu, diperlukan sebuah terapi yang sesuai dengan nilai-nilai yang dianut oleh para lansia sebagai bagian dari masyarakat Indonesia, yakni dengan mengadaptasi nilainilai keagamaan yang dimiliki lansia (Trimulyaningsih \& Subandi, 2010). Diperjelas oleh Gangdov (dalam Trimulyaningsih \& Subandi, 2010) yang menyatakan bahwa kepercayaan agama dapat berperan serta dalam intervensi dengan menggunakan pendekatan kognitif, bahkan terapi kognitif tersebut akan berperan dalam meningkatkan religiusitas individu.

Diperjelas oleh William James (dalam Tegar, 2012), bahwa pada masa lansia akan tampak usia keagamaan yang luar biasa dibandingkan dengan gejolak kehidupan sosial yang sudah mulai berakhir. Memperhatikan situasi dan kondisi yang dimiliki oleh lansia yang sudah mengalami penurunan, dari segi kemampuan fisik dan psikis dengan situasi keagamaan yang dimiliki, bila dihubungkan semestinya akan tercipta kemantapan nilai-nilai keagamaan. Para lansia akan mudah menerima kebenaran nilai-nilai keagamaan, sehingga keyakinannya semakin meningkat dan mantap.

Selain melalui teknik intervensi yang fokus pada perubahan kognitif, pada penelitian ini juga dikembangkan teknik yang dapat merubah keadaan emosi lansia. Dasar teknik yang digunakan adalah teknik relaksasi (Hawton, dkk dalam Trimulyaningsih \& Subandi, 2010). Menurut Purwanto dan
Zulaekah (2007), stresor yang dirasakan akan mengaktifkan sistem saraf simpatis yang memacu timbulnya perasaan tidak nyaman, tidak dapat santai atau relaks, sehingga memacu timbulnya depresi.

Berdasarkan pada pertimbangan tersebut, maka dalam penelitian ini akan dikembangkan sebuah terapi dengan mendengarkan bacaan AlQuran untuk menurunkan tingkat depresi pada lansia. Intervensi ini mencakup dua tipe, yakni intervensi untuk mengubah sisi kognitif serta intervensi untuk merubah sisi emosi lansia. Hal ini dilakukan dengan asumsi bahwa dua tipe invertensi tersebut mampu membuat keyakinan agama lansia semakin terinternalisasi dan mendukung pikiran adaptif lansia (Hodge dalam Trimulyaningsih \& Subandi, 2010). Tema kegiatan keagamaan berupa mendengarkan bacaan Al-Quran diasumsikan dapat membuat perubahan emosi berupa kesenangan serta kepuasan (Anderson dkk dalam Trimulyaningsih \& Subandi, 2010), serta perubahan kognisi berupa meningkatnya keyakinan agama serta kesadaran lansia akan diri dan Tuhan.

Bacaan Al-Quran dapat digunakan sebagai teknik terapi spiritual. Al-Quran dianggap sebagai terapi yang pertama dan utama, sebab di dalamnya memuat resep-resep mujarab yang dapat menyembuhkan penyakit jiwa manusia. Hal ini didasarkan pada firman Alloh dalam Al-Quran surat Al-Isra' 71:82 yang artinya:

"Dan kami turunkan dari Al-Quran suatu yang menjadi penawar dan rahmat bagi orang-orang yang beriman dan Al-Quran itu adalah tidaklah menambah kepada orang-orang yang zalim 
selain kerugian,"

Umat Islam mempercayai bahwa Al- Quran adalah kitab suci yang mengandung firmanfirman Nya dan merupakan pedoman hidup manusia. Melalui kegiatan mendengarkan bacaan Al-Quran dapat membawa lansia merasa lebih dekat dengan Tuhan serta menuntun subjek untuk mengingat dan menyerahkan segala permasalahan yang dimiliki kepada Tuhan, hal ini akan menambah keadaan pasrah (Tamaroh \& Puspitosari, 2008). Proses tersebut diperoleh dari restrukturisasi kognitif (Trimulyaningsih \& Subandi, 2010) melalui pemahaman makna dari setiap ayat Al-Quran yang diperdengarkan. Nilai-nilai agama yang terkandung dalam setiap ayat Al-Quran mampu menyediakan penjelasan atau interpretasi alternatif yang lebih adaptif atas pikiran negatif yang muncul pada benak para lansia.

Penjelasan tersebut sesuai dengan pendapat Mulyadi, Hidayah \& Mahfur (2012), yang menyatakan bahwa mendengarkan bacaan Al-Quran dapat mempengaruhi kondisi kognisi individu yaitu menjadikan individu semakin ingat kepada Tuhan. Perubahan tersebut didapat oleh individu dari memahami makna ayat dalam Al-Quran yang mengandung unsur spritual (Hawari, 2002). Oleh karena itu, melalui pengalaman beragama mendengarkan bacaan Al-Quran beserta maknanya individu dapat terbebas dari pikiran negatif (Sendiony dalam Hawari, 2002).

Selain berpengaruh pada kondisi kognitif lansia, kegiatan mendengarkan bacaan AlQuran juga dapat mempengaruhi kondisi emosi lansia yang mengalami depresi. Didasarkan pada asumsi bahwa kondisi kognisi lansia yang menyimpang dapat menghasilkan mood yang murung (Nevid, Greene, \& Ratus, 2005) maka diperlukan juga intervensi yang dapat mempengaruhi kondisi emosi lansia.

Menurut Wijaya (2009) lantunan ayatayat suci Al-Quran yang dilagukan oleh seorang qori direkam serta di perdengarkan dengan tempo yang lambat serta harmonis sendiri merupakan salah satu musik dengan intensitas 50 desibel yang dapat membawa pengaruh positif bagi pendengarnya. Menurut Widayarti (dalam Destiana, 2013) tempo murotal yang berada antara 60-70 bpm, serta bernada rendah mempunyai efek relaksasi. Heru (2008) juga menjelaskan bahwa lantunan Al-Quran dapat menurunkan hormon-hormon stres, mengaktifkan hormon endorfin alami, meningkatkan perasaan rileks, menimbulkan ketenangan, kendali emosi, pemikiran yang lebih dalam dan metabolisme yang lebih baik.

Pernyataan di atas menjelaskan bahwa mendengarkan bacaan Al-Quran mampu menciptakan kondisi ketenangan. Sebagaimana pernyataan Siswantinah (dalam Destiana, 2013) bahwa dengan mendengarkan bacaan $\mathrm{Al}$-quran individu dapat merasakan adanya penurunan depresi, kesedihan dan menciptakan ketenangan jiwa. Sejalan dengan pernyataan Siswantinah, menurut Siswanto, Windarwati \& Sekartika (2011) bacaan Al-Quran dapat digunakan sebagai teknik relaksasi spiritual untuk mendapatkan ketenangan jiwa. Dr. Ahmed AlQhadi (dalam Ibnuthohir, 2012), melalui penelitiannya membuktikan hanya dengan mendengarkan bacaan ayat-ayat Al-Qur'an, seorang muslim, baik mereka yang berbahasa Arab maupun bukan, dapat merasakan 
perubahan fisiologis yang sangat besar.

Penurunan depresi, kesedihan, memperoleh ketenangan jiwa, menangkal berbagai macam penyakit merupakan pengaruh umum yang dirasakan orang-orang yang menjadi objek penelitiannya.

Kesimpulan hasil uji coba tersebut diperkuat lagi oleh penelitian Muhammad Salim Khan yang dipublikasikan Universitas Boston. Responden pada penelitiannya mendapatkan ketenangan sampai $65 \%$ ketika mendengarkan bacaan Al-Qur'an dan mendapatkan ketenangan hanya 35\% ketika mendengarkan bahasa Arab yang bukan dari Al-Qur'an (Ibnuthohir, 2012).

Penelitian lain yang pernah dilakukan dengan melibatkan bacaan Al-Quran sebagai adalah penelitian Tamaroh dan Puspitorini (2008). Hasil penelitian menunjukkan adanya penurunan skor depresi pada lansia yang tinggal di Panti Sosial Trisna Wreda dengan rata-rata penurunan skor depresinya sebesar $1,76 \%$.

Melalui mendengarkan bacaan Al-Quran para lansia akan merasa lebih dekat dengan Tuhan serta menuntun untuk selalu ingat dan menyerahkan segala permasalahan yang dimiliki kepada Tuhan, hal ini akan menambah keadaan relaks (Destiana, 2013). Pernyataan di atas diperkuat juga oleh pendapat Ismayadi (2004) yang menyatakan bahwa terapi dengan mendengarkan bacaan Al-Quran sesuai dengan kebutuhan dan tugas perkembangan lansia.

Memperhatikan penjelasan yang telah diuraikan di atas, maka dapat disimpulkan bahwa mendengarkan bacaan Al-Quran dapat membantu mengatasi depresi pada lansia. Oleh karena itu, tujuan penelitian ini adalah untuk mengetahui efektivitas mendengarkan bacaan
Al-Quran terhadap penurunan tingkat depresi pada lansia. Hipotesis yang diajukan dalam penelitian ini adalah: 1) ada perbedaan tingkat depresi antara sebelum dan sesudah mendengarkan bacaan Al-Quran pada kelompok ekeperimen,2) tidak ada perbedaan tingkat depresi sebelum dan sesudah dari kelompok kontrol yang tidak mendengarkan bacaan AlQuran, 3) ada perbedaan tingkat depresi sesudah mendengarkan bacaan Al-Quran antara kelompok eksperimen dengan kelompok kontrol.

\section{METODE}

\section{Subjek Penelitian}

Subjek yang digunakan dalam penelitian ini adalah 26 lansia yang tinggal di Panti Sosial Tresna Wredha Budhi Luhur dengan kriteria: berusia minimal 60 tahun atau berada dalam kelompok usia lanjut, lansia yang beragama islam, lansia yang memiliki kemampuan mendengar yang baik tidak tuli, lansia dengan tingkat depresi sedang sampai depresi berat dengan nilai BDI sebesar 16-63.

\section{Metode Pengumpulan Data}

Metode pengumpulan data pada penelitian ini berupa skala inventori BDI (Beck Depresion Inventory) yang sudah diadaptasi oleh Retnowati (1990) dengan cara dibacakan oleh interviewer. Cara pemberian skor pada BDI subjek diminta untuk memilih pernyataan pada masing- masing kategori, dan diperkenankan memilih lebih dari satu pernyataan. Pernyataan yang tidak menunjukkan gejala depresi diberikan nilai 0 , nilai 1 untuk gejala ringan, nilai 2 untuk gejala sedang dan nilai 3 untuk gejala berat. Nilai 
untuk masing- masing kategori adalah nilai tertinggi yang dipilih subjek pada kategori tersebut. Kemudian nilai total yang diperoleh dihitung, dengan menjumlahkan seluruh nilai pada masing- masing kategori, jadi nilai total bergerak antara 0-63. Selanjutnya tinggi rendahnya depresi pada subjek didasarkan pada kriteri sebagai berikut: 1) 0-9 = tidak ada gejala depresi, 2) $10-15=$ depresi ringan, 3) 16-23= depresi sedang dan 24-63 = depresi berat (Retnowati, 1990).

\section{Desain Eksperimen}

Penelitian ini menggunakan desain eksperimen rancangan percobaan pretestposttest group design. Desain penelitian dapat dilihat pada Tabel 1 berikut ini:

Tabel 1. Desain eksperimen : pretest-posttest group design

\begin{tabular}{lllll}
\hline $\mathrm{R}$ & $\mathrm{KE}$ & $\mathrm{T} 1$ & $\mathrm{X}$ & $\mathrm{T} 2$ \\
\hline $\mathrm{R}$ & $\mathrm{KK}$ & $\mathrm{T} 1$ & - & $\mathrm{T} 2$ \\
\hline
\end{tabular}

Keterangan:

$\mathrm{R} \quad$ : Random Assigment

KE : Kelompok Eksperimen

KK : Kelompok Kontrol

$\mathrm{X}$ : Pemberian perlakuan mendengarkan bacaan Al-Quran

: Tanpa Perlakuan

T1 : Pretest

T2 : Posttest

Pembagian kelompok dalam penelitian ini dilakukan dengan cara random assigment, yaitu penempatan subjek pada dua kelompok (kelompok eksperimen dan kelompok kontrol) secara acak dengan tujuan agar setiap subjek memiliki kesempatan yang sama untuk di tempatkan pada kelompok eksperimen maupun kelompok kontrol. Proses pembagian kelompok ini dilakukan dengan cara membuat daftar identitas semua subjek pada selembar kertas untuk tiap subjeknya, kemudian kertas tersebut digulung dan dimasukkan dalam sebuah kotak kemudian dikocok. Hasil pengocokan pertama sebagai subjek dalam kelompok eksperimen dan sisa dari kocokan digunakan untuk menentukan kelompok kontrol.

\section{Manipulasi Variabel Independent}

Manipulasi pada penelitian ini berupa pemberian perlakuan mendengarkan bacaan AlQuran kepada kelompok eksperimen yang terbagi menjadi 3 sesi yaitu sesi pembukaan, sesi mendengarkan bacaan Al-Quran, dan sesi penutup. Berikut penjelasan setiap sesi:

1. Sesi pertama.

Sesi ini berisi pembukaan yang bertujuan untuk menjelaskan tahapan mendengarkan bacaan Al-Quran yang harus dijalani oleh subjek.

2. Sesi kedua.

Sesi ini merupakan tahap memperdengarkan bacaan Al-Quran pada subjek pada kelompok eksperimen.

3. Sesi ketiga.

Sesi ini merupakan tahap penutupan. Pada sesi ini juga terdapat evaluasi yang bertujuan agar subjek menyampaikan perasaan setelah mengikuti kegiatan mendengarkan bacaan Al-Quran.

Kelompok kontrol pada penelitian ini akan hadir pada waktu pemberian pretest dan posttest saja, sedangkan pada saat pemberian perlakuan mendengarkan bacaan Al-Quran pada kelompok eksperimen, kelompok kontrol tidak dilibatkan. Kelompok kontrol hanya datang dan tidak diperkenankan untuk mengikuti kegiatan 
mendengarkan bacaan Al-Quran. Kelompok kontrol akan berada di ruang terpisah dari kelompok eksperimen yang diberi perlakuan mendengarkan bacaan Al-Quran. Hal ini dimaksudkan untuk menghindari ancaman imitasi perilaku yaitu ancaman yang terjadi pada saat peningkatan nilai kelompok pada saat posttest karena kelompok kontrol memperoleh informasi tentang perlakuan yang diberikan dalam penelitian kepada kelompok eksperimen.

\section{Prosedur Pelaksanaan}

Penelitian mengenai efektivitas mendengarkan bacaan Al-quran terhadap penurunan tingkat depresi pada lansia dibagi menjadi dua tahap, yaitu:

1. Persiapan penelitian

Persiapan penelitian tanggal 5 April 2014

- 21 April 2014 yang meliputi; penyusunan modul, proses profesional judgement, pengajuan permohonan uji coba modul, dan mepilihan trainer.

2. Pelaksanaan Penelitian

Penelitian dilaksanakan mulai tanggal 12 Mei 2014 - 02 Juni 2014 yang meliputi; penyebaran skala BDI (pretest), pelaksanaan penelitian, penyebaran skala BDI (posttest). Pelaksanaan penyebaran data pretest dilakukan pada hari Senin-Jumat, 12 - 15 Mei 2014 di Panti Sosial Tresna Werdha Unit Budhi Luhur Kasongan, yang dibantu oleh 5 interviewer. Hasil dari pretest akan dijadikan acuan untuk pemilihan subjek. Lansia yang dijadikan subjek adalah yang memiliki tingkat depresi sedang dan berat. Pelaksanaan mendengarkan bacaan

Al-Quran terbagi menjadi 8 pertemuan yaitu selama 8 hari berturut-turut. Pelaksanaan dimulai tanggal 26 Mei - 2 Juni 2014 bertempat di Panti Sosial Tresna Werdha Budhi Luhur. Subjek diperdengarkan lafal-lafal bacaan Al-Quran beserta terjemahan tiap ayat, selama kurang lebih 30 menit melalui kaset Mp3 player murottal Al Qur'anul Karim Shaikh Mishary Rashid Al-Afasy. Surat yang digunakan untuk yaitu surat Al Fatihah, Ar Ra'd, Al Hijr, Yaa siin, Fushshilat, Muhammad, Ar Rahmaan, Al Waaqi'ah, Al Mulk, Al Insaan, An Naba', Al A'laa, Al Ghaasyiyah, Asy Syama, Al Lail, At Tiin, Al 'Alaq, Al Kautsar, Al Kaafiruun, An Nashr, Al Ikhlas, Al Falaq, An Naas.

Subjek diberikan posttest pada tanggal 02 Juni 2014, selesai pertemuan ke 8. Kegiatan ini meliputi pengumpulan data menggunakan skala inventori BDI (Beck Depresion Inventory) yang sudah diadaptasi oleh Retnowati (1990) dengan cara dibacakan oleh interviewer

\section{Teknik Analisis Data}

Teknik analisis yang digunakan adalah teknik statistik parametrik. Uji yang digunakan adalah independent sample $t$ test dan paired sample $t$ test. Independent sample $t$ test digunakan untuk menganalisis perbedaan skor kelompok eksperimen dan kelompok kontrol. Sedangkan paired sample $t$ test digunakan untuk menguji efektivitas mendengarkan bacaan Al-Quran terhadap penurunan tingkat depresi pada lansia.

\section{HASIL DAN PEMBAHASAN}

\section{Hasil}

Sebelum melaksanakan analisis data untuk menguji hipotesis peneliti terlebih dahulu melakukan uji prasyarat yang meliputi uji normalitas dan uji homogenitas. 


\section{Uji Normalitas}

Hasil pengujian normalitas data pretest menunjukkan nilai statistik sebesar 0,261 dengan taraf signifikansi $0,000(\mathrm{p}<0,05)$. Hal tersebut menunjukkan bahwa data pretest dalam penelitian ini tidak terdistribusi secara normal. Berdasarkan hasil uji normalitas tersebut, maka akan ada perubahan teknik analisis data untuk pengujian hipotesis. Menurut Sujarweni (2014) jika ada data yang tidak terdistribusi secara normal maka teknik statistik parametrik harus diganti menjadi teknik statistik non parametrik. Untuk menguji efektivitas mendengarkan bacaan Al-Quran terhadap penurunan tingkat depresi pada lansia maka uji paired sample $t$ test, akan diganti dengan uji wilcoxon. Sedangkan, untuk menganalisis perbedaan antara skor posttest kelompok eksperimen dan kelompok kontrol digunakan maka uji independent sample t test, akan diganti dengan mann-whitney U test.

\section{Uji Homogenitas}

Berdasarkan hasil uji homogenitas sebaran data, pada data skor pretest kelompok eksperiman dan kelompok kontrol menunjukkan levene statistic sebesar 0,462 dengan nilai probabilitas/sig. 0,503 ( $>>0,05)$. Hal tersebut menunjukkan bahwa subjek identik yang artinya subjek berasal dari populasi yang sama. Berdasarkan uraian di atas dapat disimpulkan bahwa data yang terkumpul memenuhi uji homogenitas dari uji prasyarat.

\section{Uji Hipotesis}

\section{a. Uji Pretest dan Posttest Kelompok \\ Eksperimen \\ Hipotesis yang diajukan dalam penelitian ini adalah ada perbedaan antara tingkat depresi}

sebelum dan sesudah mendengarkan bacaan AlQuran pada kelompok ekeperimen. Hasil analisis dengan teknik uji wilcoxon menghasilkan nilai $\mathrm{z}$ sebesar 3,189 dengan probabilitas/sig 2 tailed $=0,001$ ( $\mathrm{p}<0,05)$. Hal ini berarti ada perbedaan tingkat depresi subjek kelompok eksperimen sebelum dan sesudah diberi perlakuan mendengarkan bacaan AlQuran, sehingga hipotesis pada penelitian ini dapat diterima. Oleh karena itu, berarti juga mendengarkan bacaan Al-Quran efektif untuk menurunkan tingkat depresi pada lansia.

\section{b. Uji Pretest dan Posttest Kelompok Kontrol}

Hasil analisis dengan teknik uji wilcoxon untuk kelompok kontrol menghasilkan nilai z sebesar 1,633 dengan probabilitas/sig 2 tailed $=0,102 \quad(\mathrm{p}>0,05)$. Hasil probabilitas menunjukkan tidak ada perbedaan antara tingkat depresi sebelum dan sesudah dari kelompok kontrol. Hal tersebut berarti tidak ada penurunan tingkat depresi pada kelompok kontrol. Berarti hipotesis yang menyatakan bahwa tidak ada perbedaan tingkat depresi sebelum dan sesudah dari kelompok kontrol dapat diterima.

\section{c. Uji Posttest Kelompok Eksperimen dan Kelompok Kontrol.}

Hipotesis yang diajukan dalam penelitian ini adalah ada perbedaan tingkat depresi sesuda mendengarkan bacaan Al-Qura antara kelompok eksperime dengan kelompok kontrol. Pengujian hipotesis dalam penelitian ini menggunakan teknik mann whitney U test. Hasil perhitungan menunjukkan nilai probabilitas sebesar $0,000 \quad(p<0,05)$. Hal tersebut menunjukkan bahwa hipotesis dalam penelitian 
ini diterima. Penurunan tingkat depresi pada kelompok eksperimen dan peningkatan skor depresi pada kelompok kontrol dapat dilihat pada Tabel 2 dan Tabel 3:

Tabel 2. Tingkat Depresi pada Kelompok Eksperimen ( $N=13)$

\begin{tabular}{ccccccc}
\hline \multirow{2}{*}{ Subjek } & \multirow{2}{*}{ Skor } & Pretest & \multicolumn{2}{c}{ Posttest } & \multirow{2}{*}{ Selisih } & \multirow{2}{*}{ Keterangan } \\
\cline { 4 - 5 } & & Tingkat & Skor & Tingkat & & \\
\hline 1 & 16 & Sedang & 9 & Tidak & 7 & Turun \\
2 & 24 & Berat & 15 & Ringan & 9 & Turun \\
3 & 16 & Sedang & 10 & Ringan & 6 & Turun \\
4 & 16 & Sedang & 9 & Tidak & 7 & Turun \\
5 & 16 & Sedang & 10 & Ringan & 6 & Turun \\
6 & 16 & Sedang & 12 & Ringan & 4 & Turun \\
7 & 16 & Sedang & 13 & Ringan & 3 & Turun \\
8 & 16 & Sedang & 13 & Ringan & 3 & Turun \\
9 & 16 & Sedang & 15 & Ringan & 1 & Turun \\
10 & 17 & Sedang & 10 & Ringan & 7 & Turun \\
11 & 16 & Sedang & 11 & Ringan & 5 & Turun \\
12 & 18 & Sedang & 10 & Ringan & 8 & Turun \\
13 & 24 & Berat & 21 & Sedang & 3 & Turun \\
\hline
\end{tabular}

Tabel 3. Tingkat Depresi pada Kelompok Kontrol (N=13)

\begin{tabular}{ccccccc}
\hline \multirow{2}{*}{ Subjek } & \multirow{2}{*}{ Skor } & Pretest & \multicolumn{2}{c}{ Posttest } & \multirow{2}{*}{ Selisih } & \multirow{2}{*}{ Keterangan } \\
\cline { 3 - 5 } & & Tingkat & Skor & Tingkat & & \\
\hline 1 & 18 & Sedang & 18 & Sedang & 0 & Tetap \\
2 & 21 & sedang & 24 & Berat & 3 & Naik \\
3 & 17 & Sedang & 17 & Sedang & 0 & Tetap \\
4 & 16 & Sedang & 16 & Sedang & 0 & Tetap \\
5 & 16 & Sedang & 16 & Sedang & 0 & Tetap \\
6 & 24 & Berat & 25 & Berat & 1 & Naik \\
7 & 17 & Sedang & 17 & Sedang & 0 & Tetap \\
8 & 16 & Sedang & 16 & Sedang & 0 & Tetap \\
9 & 18 & Sedang & 18 & Sedang & 0 & Tetap \\
10 & 17 & Sedang & 17 & Sedang & 0 & Tetap \\
11 & 16 & Sedang & 16 & Sedang & 0 & Tetap \\
12 & 18 & Sedang & 18 & Sedang & 0 & Tetap \\
13 & 19 & Sedang & 20 & Sedang & 1 & Naik \\
\hline
\end{tabular}

Berdasarkan data pada kelompok eksperimen pada Tabel 2, tampak bahwa semua subjek mengalami penurunan tingkat depresi. Dari 13 subjek pada kelompok eksperimen, 10 subjek mengalami penurunan dari sedang ke ringan, 2 subjek mengalami penurunan dari sedang ke tidak depresi, dan 1 subjek mengalami penurunan dari berat ke sedang. Sedangkan pada kelompok kontrol dari 13 subjek, 3 subjek mengalami peningkatan tingkat depresi sedangkan sisanya memiliki tingkat depresi masih tetap. Hasil penelitian ini menunjukkan bahwa mendengarkan bacaan AlQuran efektif untuk menurunkan tingkat depresi pada lansia, terbukti dari penurunan tingkat depresi pada kelompok eksperimen.

\section{Uji Tambahan}

Untuk mengetahui lebih dalam mengenai 
perubahan tiap simptom depresi yang dialami oleh subjek maka dalam penelitian ini dilakukan uji tambahan. Uji tambahan ini juga dilakukan untuk mengetahui simptom depresi yang paling banyak dialami oleh para lansia. Uji tambahan dilakukan dengan melihat perbandingan antara skor pretest dan posttest tiap simptom pada kelompok eksperimen dan perbandingan antara skor pretest dan posttest tiap simptom kelompok kontrol. Terdapat 4 simptom dalam skala yaitu: simptom emosional pada aitem
1,4,7,10,11,12; simptom kognitif pada aitem $3,5,6,8,9,13,14 ;$ simptom motivasional pada aitem 2,15; simptom fisik dan vegetatif pada aitem 16,17,19,20,21.

a. Perbandingan antara skor pretestposttest tiap simptom kelompok eksperimen

Deskripsi data skor pretest dan posttest tiap simptom pada kelompok eksperimen dapat dilihat pada Tabel 4:

Tabel 4 Deskripsi data Skor Pretest-Posttest Tiap Simptom pada Kelompok Eksperimen (N:13)

\begin{tabular}{lcccccccc}
\hline \multirow{2}{*}{ Simptom } & \multicolumn{4}{c}{ Pretest } & \multicolumn{4}{c}{ Posttest } \\
\cline { 2 - 8 } & Mean & Min & Max & $\begin{array}{c}\text { Jumlah } \\
\text { skor }\end{array}$ & Mean & Min & Max & $\begin{array}{c}\text { Jumlah } \\
\text { skor }\end{array}$ \\
\hline Emosional & 4,23 & 1 & 7 & 55 & 2,31 & 0 & 6 & 30 \\
Kognitif & 3,23 & 2 & 5 & 42 & 1,15 & 0 & 4 & 15 \\
Motivasional & 1,38 & 1 & 3 & 18 & 1,15 & 0 & 3 & 15 \\
Fisik \& vegetatif & 8,62 & 6 & 13 & 112 & 7,54 & 3 & 12 & 98 \\
\hline
\end{tabular}

Nilai mean didapat dari merata-rata jumlah skor subjek sedangkan jumlah skor diperoleh dari menjumlahkan skor item yang terdapat dalam masing-masing simptom. Berdasarkan tabel di atas terlihat penurunan baik pada mean atau jumlah skor pada tiap simptomnya. Pada simptom emosional mengalami penurunan nilai mean sebesar 1,92 (4,23-2,31) dengan penurunan jumlah skor sebesar 25m(55-30). Simptom kognitif mengalami penurunan nilai mean sebesar 2,08 (3,23-1,15) dengan penurunan jumlah skor sebesar 27 (42-15). Simptom motivasional mengalami penurunan nilai mean sebesar 0,23 (1,38-1,15) dengan penurunan jumlah skor sebesar 3 (18-15). Simptom fisik dan vegetatif mengalami penurunan nilai mean sebesar 1,08 $(8,62-7,54)$ dengan penurunan jumlah skor sebesar 14 (112-98). Penurunan terbesar terdapat pada simptom kognitif.

\section{b. Perbandingan antara skor pretest- posttest tiap simptom kelompok kontrol \\ Deskripsi data skor pretest dan posttest} tiap simptom pada kelompok kontrol dapat dilihat pada Tabel 5 .

Sama dengan kelompok eksperimen, nilai mean didapat dari merata-rata jumlah skor subjek sedangkan jumlah skor diperoleh dari menjumlahkan skor item yang terdapat dalam masing-masing simptom pada kelompok kontrol. Berdasarkan tabel di atas terlihat peningkatan nilai mean serta peningkatan jumlah skor pada simptom emosional, kognitif, dan motivasional. Sedangkan simptom fisik dan vegetatif cenderung mengalami penurunan. 
Tabel 5. Deskripsi data Skor Pretest-Posttest Tiap Simptom pada Kelompok Kontrol (N:13)

\begin{tabular}{ccccccccc}
\hline \multirow{2}{*}{ Simptom } & & \multicolumn{3}{c}{ Pretest } & \multicolumn{3}{c}{ Posttest } & Jumlah \\
\cline { 3 - 7 } & Mean & Min & Max & $\begin{array}{c}\text { Jumlah } \\
\text { skor }\end{array}$ & Mean & Min & Max & $\begin{array}{c}\text { Jumor } \\
\text { skor }\end{array}$ \\
\hline Emosional & 5,54 & 3 & 10 & 72 & 5,63 & 3 & 11 & 73 \\
Kognitif & 2,23 & 0 & 4 & 29 & 2,69 & 0 & 8 & 35 \\
Motivasional & 1,77 & 1 & 3 & 23 & 1,85 & 1 & 4 & 24 \\
Fisik \& vegetatif & 8,38 & 5 & 11 & 109 & 8,15 & 5 & 10 & 106 \\
\hline
\end{tabular}

Pada simptom emosional mengalami Sedangkan simptom fisik dan vegetatif peningkatan nilai mean sebesar $0,09(5,54 \mathrm{ke}$ $5,63)$ dengan peningkatan jumlah skor sebesar 1 (72 ke 73). Simptom kognitif peningkatan nilai mean sebesar $0,46(2,23$ ke 2,69) dengan peningkatan jumlah skor sebesar 6 (29 ke 35). Simptom motivasional mengalami peningkatan nilai mean sebesar $0,08(1,77$ ke 1,85$)$ dengan mengalami penurunan nilai mean sebesar 0,23 $(8,38-8,15)$ dengan penurunan jumlah skor sebesar 3 (109-106). Peningkatan terbesar terjadi pada simptom kognitif.

Sedangkan untuk melihat perbedaan pada tiap simptom antara kelompok eksperimen dan kelompok kontrol dapat dilihat pada Tabel 6. peningkatan jumlah skor sebesar 1 (23 ke 24).

Tabel 6. Jumlah Skor Tiap Simptom

\begin{tabular}{|c|c|c|c|c|c|c|}
\hline \multirow[t]{2}{*}{ Simptom } & \multicolumn{2}{|c|}{$\begin{array}{c}\text { Kelompok } \\
\text { Eksperimen }\end{array}$} & \multirow[t]{2}{*}{ Ket. } & \multicolumn{2}{|c|}{$\begin{array}{c}\text { Kelompok } \\
\text { Kontrol }\end{array}$} & \multirow[t]{2}{*}{ Ket. } \\
\hline & Pretest & Posttest & & Pretest & Posttest & \\
\hline Emosional & 55 & 30 & Turun & 72 & 73 & Naik \\
\hline Kognitif & 42 & 15 & Turun & 29 & 35 & Naik \\
\hline Motivasional & 18 & 15 & Turun & 23 & 24 & Naik \\
\hline Fisik \& vegetatif & 112 & 98 & Turun & 109 & 106 & Turun \\
\hline
\end{tabular}

Berdasarkan Tabel 6 simptom depresi yang banyak dialami oleh para lansia adalah simptom fisik dan vegetatif direntang 98-112 untuk pretest dan rentang 106-109 untuk posttest. Hasil Tabel 15 juga menunjukkan bahwa ada penurunan skor tiap simptom pada kelompok eksperimen yang diberi perlakuan mendengarkan bacaan Al-Quran. Di sisi lain ada kenaikan skor tiap simptom pada kelompok kontrol yaitu pada simptom emosional, kognitif, dan motivasional.

Penurunan terbesar terdapat pada simptom kognitif pada kelompok eksperimen sebesar 27 (42-15). Kenaikan terbesar terjadi pada simptom kognitif pada kelompok kontrol sebesar 6 (29 ke 35). Hal tersebut menunjukkan bahwa mendengarkan bacaan Al-Quran memberikan pengaruh terhadap kondisi kognitif lansia pada kelompok eksperimen dan pada kelompok kontrol yang tidak mendengarkan bacaan Al-Quran kondisi penyimpangan kognitifnya semakin meningkat. Berdasarkan hasil tersebut terbukti bahwa mendengarkan bacaan Al-Quran efektif untuk menurunkan 
tingkat depresi pada lansia.

\section{Pembahasan}

Berdasarkan hasil analisis menunjukkan ada perbedaan yang signifikan antara kelompok eksperimen yang diberi perlakuan mendengarkan bacaan Al-Quran dan kelompok kontrol yang tidak diberi perlakuan. Hasil perhitungan menunjukkan nilai probabilitas (sign 2 tailed) sebesar 0,000 ( $\mathrm{p}<0,05)$. Dari perbandingan mean posttest kedua kelompok terlihat bahwa mean posttest kelompok eksperimen sebesar 12,15 lebih rendah dari pada mean posttest kelompok kontrol sebesar 18,31. Hal tersebut menunjukkan bahwa hipotesis yang menyatakan ada perbedaan tingkat depresi sesudah mendengarkan bacaan Al-Quran antara kelompok eksperimen dengan kelompok kontrol diterima.

Hasil penelitian ini juga menunjukkan bahwa mendengarkan bacaan Al-Quran cukup efektif untuk menurunkan tingkat depresi pada lansia. Lansia yang mendengarkan bacaan $\mathrm{Al}$ Quran akan mengalami penurunan tingkat depresi setelah mendengarkan bacaan Al-Quran. Lansia yang tidak mendengarkan bacaan AlQuran tidak mengalami penurunan tingkat depresi. Berdasarkan hasil analisis perbedaan tingkat depresi sebelum dan setelah diberi perlakuan mendengarkan bacaan Al-Quran pada kelompok eksperimen, terlihat nilai $\mathrm{z}$ sebesar 3,189 dengan probabilitas/sig 2 tailed $=0,001$ $(\mathrm{p}<0,05)$. Hal tersebut berarti hipotesis yang menyatakan bahwa ada perbedaan tingkat depresi pada lansia kelompok ekperiman sebelum dan setelah mendengarkan bacaan AlQuran dapat diterima. Selain itu, dari hasil analisis perbedaan tingkat depresi sebelum dan sesudah pada kelompok kontrol yang tidak diperdengarkan bacaan Al-Quran menunjukkan nilai z sebesar 1,633 dengan probabilitas/sig 2 tailed $=0,102 \quad(\mathrm{p}>0,05)$. Hasil tersebut menunjukkan tidak ada perbedaan antara skor pretest dan posttest dari kelompok kontrol. Hal tersebut berarti tidak ada penurunan tingkat depresi pada kelompok kontrol. Oleh karena itu hipotesis yang menyatakan bahwa tidak ada perbedaan tingkat depresi antara sebelum dan setelah pada kelompok kontrol yang tidak mendengarkan bacaan Al-Quran dapat diterima.

Mendengarkan bacaan Al-Quran juga terbukti efektif untuk menurunkan tingkat depresi pada lansia. Dibuktikan dengan adanya penurunan rata-rata skor kelompok eksperimen sebelum dan setelah diberi perlakuan. Sebelum diberi perlakuan rata-rata skor subjek sebesar 17,46 dan setelah diberi perlakuan sebesar 12,15. Berarti metode mendengarkan bacaan Al-Quran dapat digunakan untuk menurunkan tingkat depresi pada lansia. Artinya, hasil penelitian ini menunjukkan bahwa metode mendengarkan bacaan Al-Quran cukup efektif untuk menurunkan tingkat depresi pada lansia.

Berdasarkan uji tambahan terlihat bahwa simptom fisik dan vegetatif adalah simptom depresi yang paling tinggi dialami oleh para lansia. Dibuktikan dengan jumlah skor pada simptom tersebut direntang 98-112 untuk pretest dan rentang 106-109 untuk posttest. Hasil uji tambahan tersebut juga membuktikan bahwa mendengarkan bacaan Al-Quran efektif untuk menurunkan tingkat depresi pada lansia. Hal tersebut terlihat pada penurunan jumlah skor dari setiap simptom depresi pada kelompok 
eksperimen. Simptom emosional mengalami penurunan jumlah skor sebesar 25. Simptom kognitif mengalami penurunan jumlah skor sebesar 27. Simptom motivasional mengalami penurunan jumlah skor 3. Simptom fisik dan vegetatif mengalami penurunan jumlah skor sebesar 14. Penurunan terbesar terjadi pada simptom kognitif. Selain itu dari uji tambahan terdapat hasil peningkatan skor pada kelompok kontrol yaitu pada simptom emosional, kognitif, serta motivasional. Peningkatan terbesar terjadi pada simptom kognitif sebesar 6 (dari 29 ke 35).

Penurunan dan peningkatan skor pada simptom kognitif tersebut membuktikan bahwa kegiatan mendengarkan bacaan Al-Quran ini mampu merubah keadaan kognitif subjek, terutama pada subjek di kelompok eksperimen.

Melalui kegiatan mendengarkan bacaan AlQuran dapat para lansia merasa lebih dekat dengan Tuhan serta menuntun lansia untuk mengingat dan menyerahkan segala permasalahan yang dimiliki kepada Tuhan, hal ini akan menambah keadaan pasrah (Tamaroh dan Puspitosari, 2008). Penjelasan tersebut sesuai dengan pendapat Mulyadi, Hidayah \& Mahfur (2012), yang menyatakan bahwa mendengarkan bacaan Al-Quran dapat mempengaruhi kondisi kognisi individu yaitu menjadikan individu semakin ingat kepada Tuhan. Proses tersebut diperoleh dari restrukturisasi kognitif (Trimulyaningsih \& Subandi, 2010) melalui pemahaman makna dari setiap ayat Al-Quran yang diperdengarkan. Nilai-nilai agama yang terkandung dalam setiap terjemahan pada ayat Al-Quran mampu menyediakan penjelasan atau interpretasi alternatif yang lebih adaptif atas pikiran negatif yang muncul pada benak para lansia.

Selain berpengaruh terhadap kondisi kognisi lansia, mendengarkan bacaan Al-Quran juga mempengaruhi kondisi emosi para lansia. Dibuktikan pada uji tambahan di mana terdapat penurunan skor pada simptom emosional kelompok eksperimen sebesar 25 (55-30). Bacaan Al-Quran mampu memberikan ketenangan bagi para lansia yang mengalami depresi. Sebagaimana pendapat Heru (2008) yang menjelaskan bahwa lantunan Al-Quran dapat menurunkan hormon-hormon stres, mengaktifkan hormon endorfin alami, meningkatkan perasaan rileks, menimbulkan ketenangan, kendali emosi, pemikiran yang lebih dalam dan metabolisme yang lebih baik.

Mendengarkan bacaan Al-Quran yang merupakan salah satu kegiatan spiritual telah mampu mengatasi kondisi depresi yang dialami para lansia. Para lansia yang mendengarkan bacaan Al-Quran telah mengalami perubahan pada kondisi kognitif maupun emosinya. Hal tersebut sesuai dengan pendapat Taylor \& Anderson (dalam Trimulyaningsih \& Subandi, 2010) kegiatan yang disertai dengan kegiatan bertema keagamaan dapat meningkatkan kesadaran spiritual individu, yang diasumsikan dapat mengubah keadaan emosi individu berupa kesenangan dan kepuasan, serta terjadi perubahan kognisi berupa meningkatnya keyakinan agama dan kesadaran individu akan diri, lingkungan sekitar dan Tuhan.

Hasil dari pembahasan di atas membuktikan bahwa mendengarkan bacaan $\mathrm{Al}$ Quran untuk menurunkan tingkat depresi pada lansia. Pernyataan tersebut juga didukung oleh 
pendapat Ahmed Al-Qhadi (dalam Ibnuthohir, 2012) bahwa dengan mendengarkan bacaan ayat-ayat Al-Qur'an, seorang dapat merasakan perubahan fisiologis yang sangat yang berpengaruh pada penurunan depresi, kesedihan, dan memperoleh ketenangan jiwa. Penelitian ini juga sejalan dengan penelitian yang dilakukan oleh Tamaroh dan Puspitorini (2008). Hasil penelitian menunjukkan adanya penurunan skor depresi pada lansia yang tinggal di Panti Sosial Tresna Wredha dengan rata-rata penurunan skor depresinya sebesar $1,76 \%$.

Hal tersebut di atas juga sesuai dengan pendapat Siswantinah (dalam Destiana, 2013 bahwa dengan mendengarkan bacaan Al-quran individu dapat merasakan adanya penurunan depresi, kesedihan dan menciptakan ketenangan jiwa. Oleh karena itu, bagi para lansia yang menurut William James (dalam Tegar, 2012), pada masa lansia usia keagamaan akan tampak luar biasa dibandingkan dengan gejolak kehidupan sosial yang sudah mulai berakhir, mendengarkan bacaan Al-Quran ini sangat memberi pengaruh terhadap penurunan tingkat depresi. Memperhatikan situasi dan kondisi yang dimiliki oleh lansia yang sudah mengalami penurunan, dari segi kemampuan fisik dan psikis dengan situasi keagamaan yang dimiliki, bila dihubungkan semestinya akan tercipta kemantapan nilai-nilai keagamaan. Para lansia menjadi mudah menerima kebenaran nilai-nilai keagamaan, sehingga keyakinannya semakin meningkat dan mantap. Melalui mendengarkan bacaan Al-Quran para lansia akan merasa lebih dekat dengan Tuhan serta menuntun untuk selalu ingat dan menyerahkan segala permasalahan yang dimiliki kepada Tuhan, hal ini akan menambah keadaan relaks (Destiana, 2013).

Berdasarkan penjelasan di atas dapat ditarik kesimpulan bahwa mendengarkan bacaan Al-Quran efektif untuk menurunkan tingkat depresi pada lansia. Lansia yang mendengarkan bacaan Al-Quran mengalami penurunan tingkat depresi daripada lansia yang tidak mendengarkan bacaan Al-Quran. Akan tetapi, disisi lain penelitian ini belum dapat menjelaskan mengenai seberapa lama efek dari mendengarkan bacaan Al-Quran berpengaruh terhadap penurunan tingkat depresi lansia. Hal tersebut dikarenakan peneliti tidak melakukan posttest tambahan setelah posttest pertama. Selain itu, penentuan surah dalam Al-Quran belum dapat terfokus pada kandungan terjemahan tiap ayatnya, sehingga belum diketahui surah-surah tertentu dalam Al-Quran yang dapat memberikan pengaruh khususnya pada kondisi kognisi para lansia yang mengalami depresi.

\section{PENUTUP}

\section{Kesimpulan}

Berdasarkan hasil analisis menunjukkan ada perbedaan yang signifikan antara kelompok eksperimen yang diberi perlakuan mendengarkan bacaan Al-Quran dan kelompok kontrol yang tidak diberi perlakuan. Hasil perhitungan menunjukkan nilai probabilitas sebesar $0,000(\mathrm{p}<0,05)$. Hasil penelitian ini juga menunjukkan bahwa mendengarkan bacaan AlQuran cukup efektif untuk menurunkan tingkat depresi pada lansia. Berdasarkan hasil analisis perbedaan tingkat depresi sebelum dan setelah 
diberi perlakuan mendengarkan bacaan AlQuran pada kelompok eksperimen, terlihat nilai Z sebesar 3,189 dengan probabilitas/sig 2 tailed $=0,001 \quad(\mathrm{p}<0,05)$. Selain itu, dari hasil analisis perbedaan tingkat depresi sebelum dan setelah pada kelompok kontrol yang tidak drperdengarkan bacaan Al-Quran menunjukkan nilai z sebesar 1,633 dengan probabilitas/sig 2 tailed $=0,102(\mathrm{p}>0,05)$.

Berdasarkan uji tambahan terlihat bahwa simptom fisik dan vegetatif adalah simptom depresi yang paling tinggi dialami oleh para lansia. Dibuktikan dengan jumlah skor pada simptom tersebut direntang 98-112 untuk pretest dan rentang 106-109 untuk posttest. Hasil uji tambahan tersebut juga membuktikan bahwa mendengarkan bacaan Al-Quran efektif untuk menurunkan tingkat depresi pada lansia. Hal tersebut terlihat pada penurunan jumlah skor dari setiap simptom depresi pada kelompok eksperimen. Simptom emosional mengalami penurunan jumlah skor sebesar 25. Simptom kognitif mengalami penurunan jumlah skor sebesar 27. Simptom motivasional mengalami penurunan jumlah skor 3. Simptom fisik dan vegetatif rata- mengalami penurunan jumlah skor sebesar 14. Penurunan terbesar terjadi pada simptom kognitif. Selain itu dari uji tambahan terdapat hasil peningkatan skor pada kelompok kontrol yaitu pada simptom emosional, kognitif, serta motivasional. Peningkatan terbesar terjadi pada simptom kognitif sebesar 6 (dari 29 ke 35).

\section{Saran}

\section{Kepada Pengurus Panti}

Hasil penelitian ini dapat dijadikan informasi bagi pengurus panti agar dapat mengupayakan cara untuk mengatasi permasalahan lansia yang tinggal di panti terutama permasalahan depresi yang dialami para lansia. Permasalahan depresi pada para lansia dapat diatasi dengan cara menyentuh sisi religiusitas yaitu dengan memperdengarkan bacaan Al-Quran bagi para lansia untuk proses penyembuhan.

\section{Kepada Peneliti Selanjutnya}

Penelitian lanjutan dengan waktu pelaksanaan pemberian bacaan Al-Quran yang lebih lamaaitu lebih dari 8 hari, sehingga mungkin akan menimbulkan efek yang lebih besar dalam menurunkan skor depresi pada lansia. Selain itu, perlu adanya pengukuran kedua (posttest ke 2) setelah mendengarkan bacaan Al-Quran untuk melihat seberapa lama bacaan Al-Quran yang diberikan mempengaruhi kondisi depresi subjek. Penelitian selanjutnya dapat mengupayakan untuk menentukan suratsurat dalam Al-Quran yang lebih spesifik untuk menciptakan perubahan kognitif yang besar pada lansia yang mengalami gangguan depresi.

\section{DAFTAR PUSTAKA}

Beck, A.T. (1985). Depression Causes Treatment. Philadelphia: University of Pennsylvania. Buletin Jendela Data dan Informasi Kesehatan Kementrian Kesehatan RI Semester I. 2013. Jakarta.

Destiana, R. (2012). Pengaruh Terapi Murottal terhadap Berat Badan pada Bayi Prematur di Ruang Perinatologi RSUD Banyumas. Skripsi. Purwokerto: Universitas Jendral Soedirman.

Hawari, D. (2002). Dimensi Religi dalam Praktek Psikiatri dan Psikologi. Jakarta: Balai Penerbit Fakultas Kedokteran Universitas Indonesia.

Heru. (2008). Ruqyah Syar'i Berlandaskan Kearifann Lokal. Retrieved from: 
http://trainermuslim.com/feed/rss.

(Diunduh 07 Maret 2014, pukul 13.00 WIB).

Ibnuthohir. (2012). Al-Quran: Lihat, Dengar dan Rasakan. Retrieved from: http://www.lingkaran.org/al-quran-lihatdengar-dan-rasakan.html. (Diunduh pada 23 Januari 2013, pukul 14.00 WIB).

Irawan, H. (2013). Gangguan Depresi pada Lanjut Usia. Jurnal CDK-210/vol.40 no.11.www.kalbemed.com/.../06_210Gan gguan\%20Depresi\%20pada\%20Lanjut\% 20Usia.pdf. (Diunduh pada 13 Februari 2014, pukul 11.00 WIB).

Ismayadi. (2004). Proses Menua. Retrieved from:

http://library.usu.ac.id/download/fk/keper awatan-ismayadi.pdf. (Diunduh pada 03 Juli 2014, pukul 14.00 WIB).

Maulana, R. (2011). Depresi pada Lansia. Retrieved from: http://razimaulana.wordpress.com/2011/0 3/08/depresi-pada-lansia-2/ (Diunduh pada 15 Desember 2013 pukul 11.00 WIB).

Mulyadi; Hidayah, R. \& Mahfur. (2012). Kecemasan dan Psikoterapi Islam. Jurnal.ejournal.uin.malang.ac.id/index/ph p/lemlit/article/download/2034/pdf.

(Diunduh 14 Maret 2014, pukul 09.00 WIB).

Nevid, J.S.; Rathus, S.A. \& Green, B. 2005. Psikologi Abonormal. Edisi Kelima: Jilid dua. Jakarta: Erlangga.

Probosuseno. 2012. Strategi Penanganan Medis Usia Lanjut. Makalah. (Disajikan dalam Temu Ilmiah Ikatan Psikologi Perkembangan Indonesia di Fakultas Psikologi UGM).

Purwanto, S., \& Zulaekah, S. 2007. Pengaruh Pelatihan Relaksasi Religius untuk Mengurangi Gangguan Insomnia. Jurnal. http://psikologi.ums.ac.id/wpcontent/uploads/2013/08/2013-08-28PENGARUH-PELATIHANRELAKSASI-RELIGIUS-UNTUKUAD.pdf. (Diunduh pada 28 Desember 2013, pukul 17.00 WIB). Republika.com. 2012. Hati-hati, Wanita Lansia Lebih
Rentan

Depresi!. http://www.republika.co.id/berita/gayahidup/info-sehat/12/04/10/m28rjthatihati-wanita-lansia-lebih-rentandepresi. (Diunduh diunggah 12 Desember 2013 pukul 21.22 WIB ).

Retnowati, S. 1990. Terapi Kognitif dan Terapi Perilaku pada Penanganan Gangguan Depresi. Tesis. Yogyakarta:

Pasca Sarjana Fakultas Psikologi Universitas Universitas Gadjah Mada.

Sindonews.com.. 2013. Tiap Tahun Jumlah Sakit Jiwa Lansia Meningkat di Indonesia.http://soccer.sindonews.com/re $\mathrm{ad} / 2013 / 10 / 09 / 15 / 792353 /$ tiap-tahunjumlah-sakit-jiwa-lansia-meningkat-diindonesia. (Diunduh 12 Desember 2013 pukul 21.00 WIB).

Siswanto; Windarwati, H.D.; \& Sekartika, D. 2011. Pengaruh Terapi Suara Tartil AlQuran terhadap Penurunan Tingkat Insomnia pada Lanjut Usia di Panti Wredha Muhammadiyah Kota Probolinggo.http://old.fk.ub.ac.id/artikel/ id/filedownload/keperawatan/dian\%20sek artika.pdf. (Diunduh 28 Maret 2014, pukul $12.00 \mathrm{WIB}$ ).

Suardiman, S.P. 2011. Psikologi Usia Lanjut. Yogyakarta: Gadjah Mada University Press.

Sujarweni, V.W. 2014. SPSS untuk Penelitian. Yogyakarta: Pustaka Baru Press.

Sumirta, I. N. 2011. Depresi pada Lansia. Makalah.http://ramakrisnahare.blogspot.c om/2011/03/depresi-pada-lansia.html.

(Diunduh 16 Januari 2014, pukul 13.00 WIB).

Syaamil Al-Quran Terjemahan Per Kata. 2010. Bandung: Sygma Publishing.

Syamsuddin. 2006. Depresi pada Lansia. Artikel.http://www.kemsos.go.id/modules .php? name $=$ New $\&$ file $=$ article $\&$ sid $=208$.

(Diunduh 16 Desember 2013, pukul 12.00 WIB).

Tamaroh, E., \& Puspitosari, W.A. 2008. Pengaruh Mendengar Bacaan Al-Quran Terhadap Skor Depresi Lansia Di Panti Sosial Trisna Werdha Unit Budi Luhur, 
Kasongan, Bantul, Yogyakarta. Jurnal. http://publikasi.umy.ac.id/index.php/pend -dokter/article/view/3944/3271.(Diunduh pada 15 November 2014, pukul 17.00 WIB).

Tegar, E. 2012. Perkembangan Jiwa Agama Pada Masa Usia Lanjut. Makalah. http://erwinsyahtegar.blogspot.com/2012/ 03/perkembangan-jiwa-agama-padamasa-usia.html. (Diunduh pada 15 November 2014, pukul 07.00 WIB).

Trimulyaningsih, N. \& Subandi, M.A. 2010. Terapi Kognitif-Perilakuan Religius untuk Menurunkan Gejala Depresi. Jurnal Intervensi Psikologi, 2(1),

Wijaya, M. 2009. Analisis Perbandingan Spektral Musik Murottal \& Klasik Mozzart.Makalah.http://mossawijaya.blo g.uns.ac.id/analisis-perbandinganspektral-musik-murottal-alquran-denganmusik-klasik-mozzart-sebagai-acuanuntuk-meningkatkan-kemampuanspasial-temporal-seseorang. (Diunduh 15 Maret 2014, pukul 13.00 WIB).

Wilkinson, G. 1992. Depression. Alih Bahasa: Meitasari. Jakarta: Arcan. 